\title{
FREQUENCY-DEPENDENT PROPERTIES OF InGaAs BOW-TIE DETECTORS IN TERAHERTZ RANGE
}

\author{
L. Minkevičius ${ }^{a, b}$ I. Kašalynas ${ }^{a}$, D. Seliuta ${ }^{a}$, V. Tamošiūnas ${ }^{a, b}$, and G. Valušis ${ }^{a, b}$ \\ a Semiconductor Physics Institute, Center for Physical Sciences and Technology, A. Goštauto 11, LT-01108 Vilnius, Lithuania \\ E-mail: linas.minkevicius@ff.stud.vu.lt \\ ${ }^{\mathrm{b}}$ Faculty of Physics, Vilnius University, Sauletekio 9, LT-10222 Vilnius, Lithuania
}

Received 23 October 2009; revised 26 January 2010; accepted 18 March 2010

\begin{abstract}
Finite-difference time-domain simulation results in bow-tie InGaAs diodes are presented. Dependences of electric field amplitude on frequency were investigated for various device shapes and sizes. It was shown that two metallized parts of the bow-tie type detector act as the separate antennas causing thus the experimentally observed fast sensitivity reduction at 1.63 , 1.83, and $2.51 \mathrm{THz}$ frequencies. Moreover, it has been demonstrated that the estimated effective average refractive index of the region around the antenna for all investigated angles and dimensions is nearly constant, and this constant value could be used for further estimation of frequency dependent properties in the case of other slightly altered bow-tie detector geometry.
\end{abstract}

Keywords: terahertz emission, InGaAs, antenna effects, FDTD method

PACS: $73.21 . \mathrm{Fg}$, 78.55.Cr, 78.67.De

\section{Introduction}

Promising implementation of terahertz (THz) frequency range, for security aims in particular, stimulates the search of new solutions in development of sensitive and wideband sensors operating at room temperature. Evidently, the most straightforward way is to employ commercially available infrared microbolometer array for real-time image recording in $\mathrm{THz}$ frequency range as demonstrated recently [1]. A camera has been developed for 8-14 $\mu \mathrm{m}$ wavelength range, but it appears to be able to record images at $\mathrm{THz}$ range with rather low signal-to-noise ratio. An alternative option can be the usage of nanometric field effect transistors (nanoFETs) for $\mathrm{THz}$ imaging array construction. Transistor operation is based on plasma waves excitation at temperatures normally below liquid nitrogen one [2]. At room temperature, plasma oscillations in nanoFET channel are strongly damped, however, the transistor still can operate as broadband $\mathrm{THz}$ detector due to signal rectification on nonlinear channel resistance [3]. Recording metallic object's THz images with commercial Fujitsu nanoFET at $0.6 \mathrm{THz}$ [4] has been demonstrated experimentally. Furthermore, it has also been shown that such a kind of transistors even without an additional incident radiation coupling can successfully be used for room temperature imaging at significantly higher fre- quencies, namely, at $1.63 \mathrm{THz}$ [5]. It is believed that the image quality can be improved by pushing the current through the channel with two-dimensional electron gas [6]. Fast photoresponse property - in the range of $2 \mathrm{GHz}$ [7] - of nanoFETs indicates their potential for real-time imaging, however, transistor-based devices are very sensitive to the static charge, their fabrication is quite complicated and relies on semiconductor nanotechnology process accompanied by costly electron lithography. Therefore, a more simple approach would be desirable, in particular, from the processing point of view.

Very recently, room temperature $\mathrm{THz}$ images below $1 \mathrm{THz}$ have been recorded using InGaAs bow-tie diodes [8]. The device operation principle is based on non-uniform electron heating in bow-tie diode with a spatially broken symmetry - one of its leaves is metallic while another one is semiconductor containing two-dimensional electron gas $[9,10]$. In order to improve the device operation, in particular, above $1 \mathrm{THz}$, one needs to know the incident radiation coupling related effects. Moreover, one should bear in mind the fact that these devices suffer from a rapid, oscillatory-behaviour sensitivity decay once irradiation frequency increases. Therefore, additional numerical investigation is required to address this issue, since possible antenna-related effects due to device shape and 
Table 1. Detector dimensions.

\begin{tabular}{cccc}
\hline Part & $\begin{array}{c}\text { Width, } \\
y \text { direction }(\mu \mathrm{m})\end{array}$ & $\begin{array}{c}\text { Length, } \\
z \text { direction }(\mu \mathrm{m})\end{array}$ & Coating \\
\hline$A$ & 50 & 100 & metallized \\
$B$ & 50 & from 125 to 295 & metallized \\
$C$ & 50 & from 5 to 175 & not metallized \\
$D$ & 50 & 125 & metallized \\
\hline
\end{tabular}

contacts' size can have strong effect on the operation conditions. In addition, it is important to evaluate the influence exerted on electromagnetic field by separate parts of antenna.

\section{Simulation method}

\subsection{Three-dimensional FDTD method}

Distribution of the electromagnetic fields in the space of semiconductor of the $\mathrm{THz}$ detector was simulated by three-dimensional (3D) finite-difference timedomain (FDTD) method [11]. The aim was to estimate electromagnetic field distributions in differently designed InGaAs bow-tie diode and to explore the frequency dependence of electric field. The simulation results let us find the best possible detector dimensions according to target wavelengths and also to find out the most appropriate antenna design. Furthermore, this would let us to replace the silicon lens which is currently used to concentrate the incident radiation [10]. The 3D FDTD method requires a lot of computer resources (for example, 6 arrays for storing current values of electric and magnetic field components even for a moderately sized simulation area of $200 \times 200 \times 200$ cells consume nearly 0.4 GB of memory at 8 bytes per double precision value) and calculation time (only several updates per second of all values are usually possible due to limited throughput of PC, hence, typical simulations with hundreds of thousands of steps might take from several hours to days to complete). Therefore, several limitations were introduced: (i) it was assumed that the influence of electrons in very thin two dimensional electron gas layer to wave propagation was negligible, and (ii) the metal layer was approximated as an ideal conductor.

\subsection{Detector dimensions}

Simulated detector design and dimensions were chosen according to a particular bow-tie detector, the prototype of which with a hemispherical silicon lens, as experiments have shown, was quite sensitive for $\mathrm{THz}$

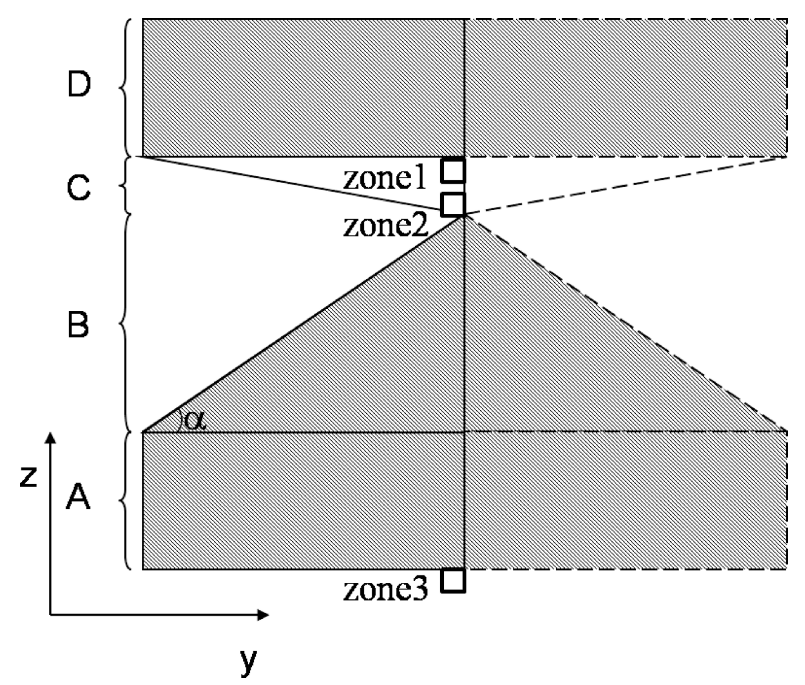

Fig. 1. Schematic view of the device. The device was divided into four parts: $A$ and $D$ are electrodes, $B$ part concentrates incident radiation into active region, $C$ is active region. Half of the detector was simulated (areas delineated by a solid line), field distribution on the other side was symmetrical. Zones 1,2, and 3 indicate cells where electric field $E_{z}$ was registered. Metallized parts are marked as black shaded areas. The diode is depicted not to scale aiming to illustrate general view and to indicate the position of the sharp metal "tip".

radiation [10]. Characteristic design of the bow-tie detector is shown schematically in Fig. 1. Surfaces in $A$, $B, D$ parts in most simulations were metallized; $C$ part surface was not metallized in all simulations. When we were simulating the influence of antenna parts on detector resonances, metallization was taken off from $A$ and $B$ parts, then from $D$ part. Dimensions of simulated detector parts are listed in Table 1. The dimensions of the $A$ and $D$ parts were always fixed, but the $B$ part width was fixed and the length was changed subject to angle $\alpha$.

Typical simulation zone and simulated electric field amplitude $E$ distribution is shown in Fig. 2. Rectangular sides mark simulation zone size which was changed in various simulations. Arrow shows the direction of incident wave propagation. Its polarization was oriented along the bow-tie diode. Simulation area with InP substrate is shown in darker style, detector metallized parts are marked (orange online). Dashed line marks interface between two simulation zones. In one of them (left side) the reflected field was simulated, while on the right side the incident and reflected fields were superimposed. Wave, which had crossed the substrate, was "absorbed" due to boundary conditions in the last simulation cell. The same occured with the reflected wave, which was also "absorbed" due to boundary conditions in the front plane of simulation area. 


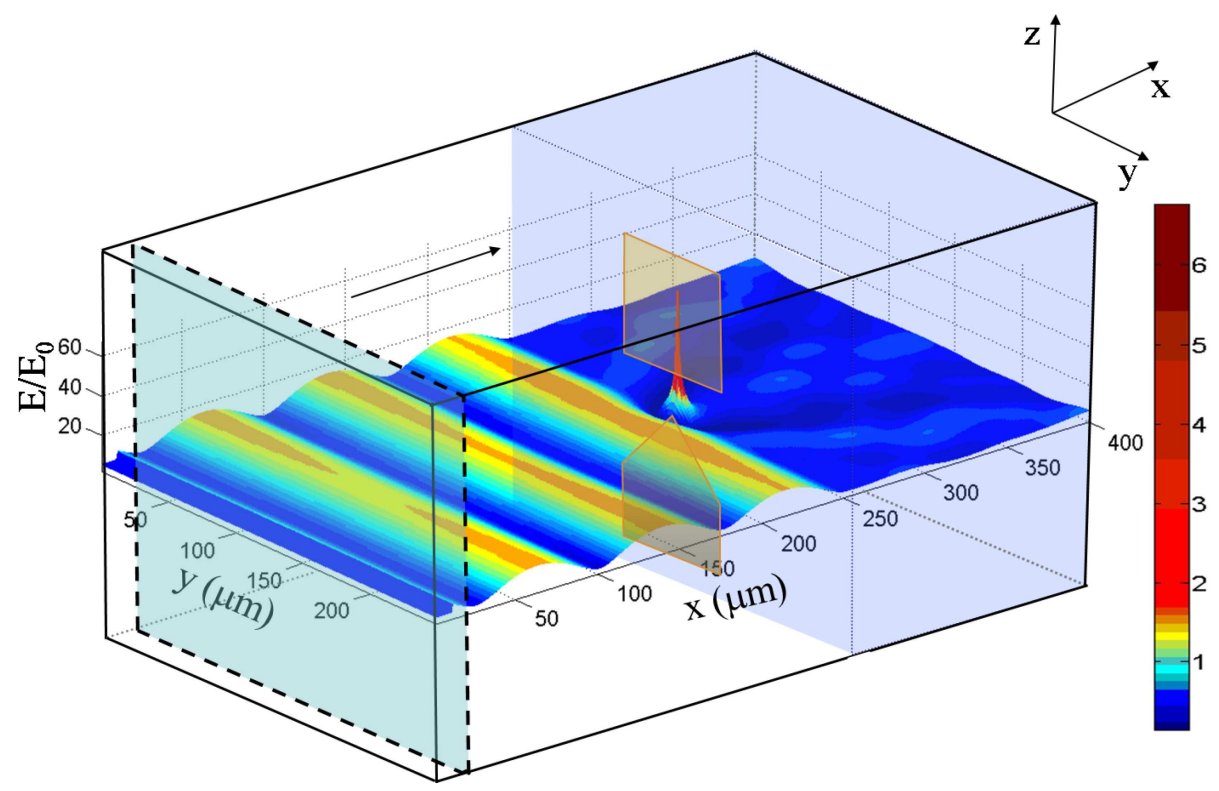

Fig. 2. Electric field $E$ amplitude distribution near the bow-tie detector apex space was simulated using three-dimensional finite-difference time-domain (3D-FDTD) method [11]. Incident wave direction is marked by an arrow. Simulation zone, where InP substrate is placed, is darkened. Detector metallized part shapes on substrate surface are schematically marked by a solid line (orange online). Boundary between two simulation zones is marked by a dashed line.

\subsection{Simulation specification}

At first, we have determined the wave propagation time for steady solutions. Electric field amplitude $E_{z}$ to incident wave amplitude $E_{0}$ ratio $E_{z} / E_{0}$ was simulated and its dependence on frequency for different number of steps was registered. The result for different step numbers was calculated at zone 2, with angle $\alpha$ and the resolution values fixed. We found out that results were steady when the number of simulation steps exceeded 120000. For further simulation we were using 135000 steps (wave propagation time $t=0.225 \mathrm{~ns}$ ) in order to have correct simulation results.

The first task was to evaluate $E_{z} / E_{0}$ dependence on the simulation angle $\alpha$. Simulation zone sizes along $x$, $y, z$ axes were $100,400,260$ cells, respectively. Steps in $z$ axis direction were 5 times larger than in $x, y$ direction for more accurate $B$ part apex simulation. Simulated metallized detector parts' dimensions were as follows: $A, B$, and $D$ parts for $y$ direction were $50 \mu \mathrm{m}$, for $z$ direction $A$ was $100 \mu \mathrm{m}, B$ (125-295) $\mu \mathrm{m}, D 125 \mu \mathrm{m}$. $C$ part was not metallized. The simulation result was registered by varying the simulation angle $\alpha$ in zone 2 and zone 1 . Resolution and step number were kept constant. Detector was "illuminated" by a plane wave linearly polarized in $z$ direction. Such polarization was imposed by the design of the detector - a much weaker coupling (and, therefore, sensitivity) is expected in the case of $y$-polarized light due to (i) smaller metallized antenna dimensions in this direction and (ii) location of the "tip" of the triangular active region in the middle of the antenna.

\subsection{The effective refractive index}

FDTD simulations are extremely time-consuming, with typical computation times of several days or even weeks for a single configuration of the detector. Therefore, the prototyping speed of future detectors would increase dramatically, if a relation between the sizes of metallized parts and the frequencies of resonances with more or less stable parameters could be found and understood. Such relation is extremely simple in a classical case of the dipole antenna, where the length of each of the two antenna parts is simply equal to the quarter wavelength of the electromagnetic wave. Unfortunately, such model cannot be applied analytically in our case, because even in a simplified model at least two materials (vacuum and substrate) with different refractive indices should be taken into account and it is not very clear in advance how to include the changing width of the metallization and mixed shapes. However, one can try to define the effective refractive index from computation results. Frequencies of the first few amplitude maxima values were taken for each simulated angle $\alpha$. The amplitude values used were recorded at zone 1 and at zone 2 (see Fig. 1), where incident radiation is mainly concentrated by metallized leaf (spike of the $B$ part). Wavelength was calculated from the obtained resonance frequency. Detector $A+B$ parts' and $D$ 
Table 2. Calculations of the effective refractive index.

\begin{tabular}{ccccccc}
\hline$\alpha$ (deg.) & Res. no. & $f_{\text {res }}, \mathrm{GHz}$ & $L_{A+B}, \mathrm{~mm}$ & Max. type & $\boldsymbol{n}_{\text {eff }}$ & $\lambda, \mathrm{mm}$ \\
\hline \multirow{3}{*}{80.4} & 1 & 125 & 0.4 & $\lambda / 4$ & $\mathbf{1 . 5 0}$ & 2.40 \\
& 2 & 393 & 0.4 & $3 \lambda / 4$ & $\mathbf{1 . 4 3}$ & 0.76 \\
& 3 & 681 & 0.4 & $5 \lambda / 4$ & $\mathbf{1 . 3 8}$ & 0.44 \\
& 4 & 900 & 0.4 & $7 \lambda / 4$ & $\mathbf{1 . 4 6}$ & 0.33 \\
\cline { 2 - 7 } 75.9 & 1 & 156 & 0.3 & $\lambda / 4$ & $\mathbf{1 . 6}$ & 1.92 \\
& 2 & 506 & 0.3 & $3 \lambda / 4$ & $\mathbf{1 . 4 8}$ & 0.59 \\
& 3 & 837 & 0.3 & $5 \lambda / 4$ & $\mathbf{1 . 4 9}$ & 0.36 \\
72.6 & 4 & 1143 & 0.3 & $7 \lambda / 4$ & $\mathbf{1 . 5 3}$ & 0.26 \\
\hline \multirow{4}{*}{68.2} & 1 & 218 & 0.25 & $\lambda / 4$ & $\mathbf{1 . 3 8}$ & 1.38 \\
& 2 & 593 & 0.25 & $3 \lambda / 4$ & $\mathbf{1 . 5 2}$ & 0.51 \\
& 3 & 962 & 0.25 & $5 \lambda / 4$ & $\mathbf{1 . 5 6}$ & 0.31 \\
\cline { 2 - 7 } & 1 & 237 & 0.23 & $\lambda / 4$ & $\mathbf{1 . 3 8}$ & 1.27 \\
72.6 (recorded below $D$ part) & 2 & 656 & 0.23 & $3 \lambda / 4$ & $\mathbf{1 . 4 9}$ & 0.46 \\
& 3 & 1100 & 0.23 & $5 \lambda / 4$ & $\mathbf{1 . 4 8}$ & 0.27 \\
\cline { 2 - 7 } & 1 & 274 & 0.13 & $\lambda / 4$ & $\mathbf{2 . 1 0}$ & 1.1 \\
& $\min$ & 731 & 0.13 & $\lambda / 2$ & $\mathbf{1 . 5 8}$ & 0.41 \\
& 2 & 1045 & 0.13 & $3 \lambda / 4$ & $\mathbf{1 . 6 6}$ & 0.29 \\
\hline
\end{tabular}

part length was known, while plausible maximum type (quarter wave number which has matched antenna dimension) was guessed at and $n_{\text {eff }}$ (effective refractive index) was calculated as

$$
n_{\mathrm{eff}}=\frac{c}{4 f_{\mathrm{res}}} \frac{N}{L_{A+B}},
$$

where $n_{\text {eff }}$ is an effective refractive index, $c$ is the speed of light in vacuum, $f_{\text {res }}$ is resonance frequency obtained from the simulations, $N$ is number of quarter wavelengths corresponding to the overall length of $A$ and $B$ antenna parts, $L_{A+B}$. If $n_{\text {eff }}$ stays nearly constant for a certain range of angles and dimensions, one can immediately estimate the expected resonance frequencies for the intermediate angles and dimensions as

$$
f_{\text {res }}^{\prime}=\frac{c}{4 n_{\text {eff }}} \frac{N}{L_{A+B}^{\prime}},
$$

without further simulations. The results are summarized in Table 2.

\section{Simulation results and discussion}

\subsection{Electric field $\left(E_{z} / E_{0}\right)$ dependence on frequency and contact angles}

In order to find out how to achieve a better incident radiation coupling to active region, we simulated how the electric field $\left(E_{z} / E_{0}\right)$ dependence on frequency was affected by the angle $\alpha$ changes in $B$ part. It should be noted that for this particular purpose, $E_{z}$ component is the most important as the other simulated electric and magnetic field components have negligible in- fluence: $E_{y}, H_{z}, H_{x}$ are approaching 0 near the symmetry plane, $E_{x}$ is directed perpendicularly to the conducting plane, $H_{y}$ is parallel to it, leaving thus $E_{z}$ component mainly "responsible" for the non-uniform electron heating. Simulation results taken at zone 2 are shown in Fig. 3(a), and results calculated at zone 1 are in Fig. 3(b). It is clearly seen that the maxima of amplitude values are different and dependent on angle $\alpha$. When the distance between zone 1 and zone 2 is very small (angle $\alpha=75.9^{\circ}$ ) the biggest electric field amplitude is obtained. In Fig. 3(a) we can clearly see that resonances for $E_{z} / E_{0}$ (values calculated in zone 2) move to shorter wavelengths when the angle $\alpha$ value is decreased. Maxima of amplitudes simulated in zone 1 act conversely, their positions do not depend on angle $\alpha$ and peak values are 4 times smaller because of the form of $D$ part.

It is important to mention several essential aspects visible from Fig. 3. First, metallized detector leaf and detector contact pads act as two separate antennas. Second, displacement of obtained electric field spectrum is associated with the change of $A$ and $B$ zone lengths (decreased length shifts the electric field maxima to shorter wavelengths). Moreover, when the electric field is simulated at zone 2, visible reduction of its peak amplitude is observed due to the resonance frequency shift for all simulated angles.

\subsection{Influence of antenna parts on detector resonances}

In order to explore how different parts of the antenna affect the electric field distribution in the diode, we proceeded with further simulations for alternately changed 

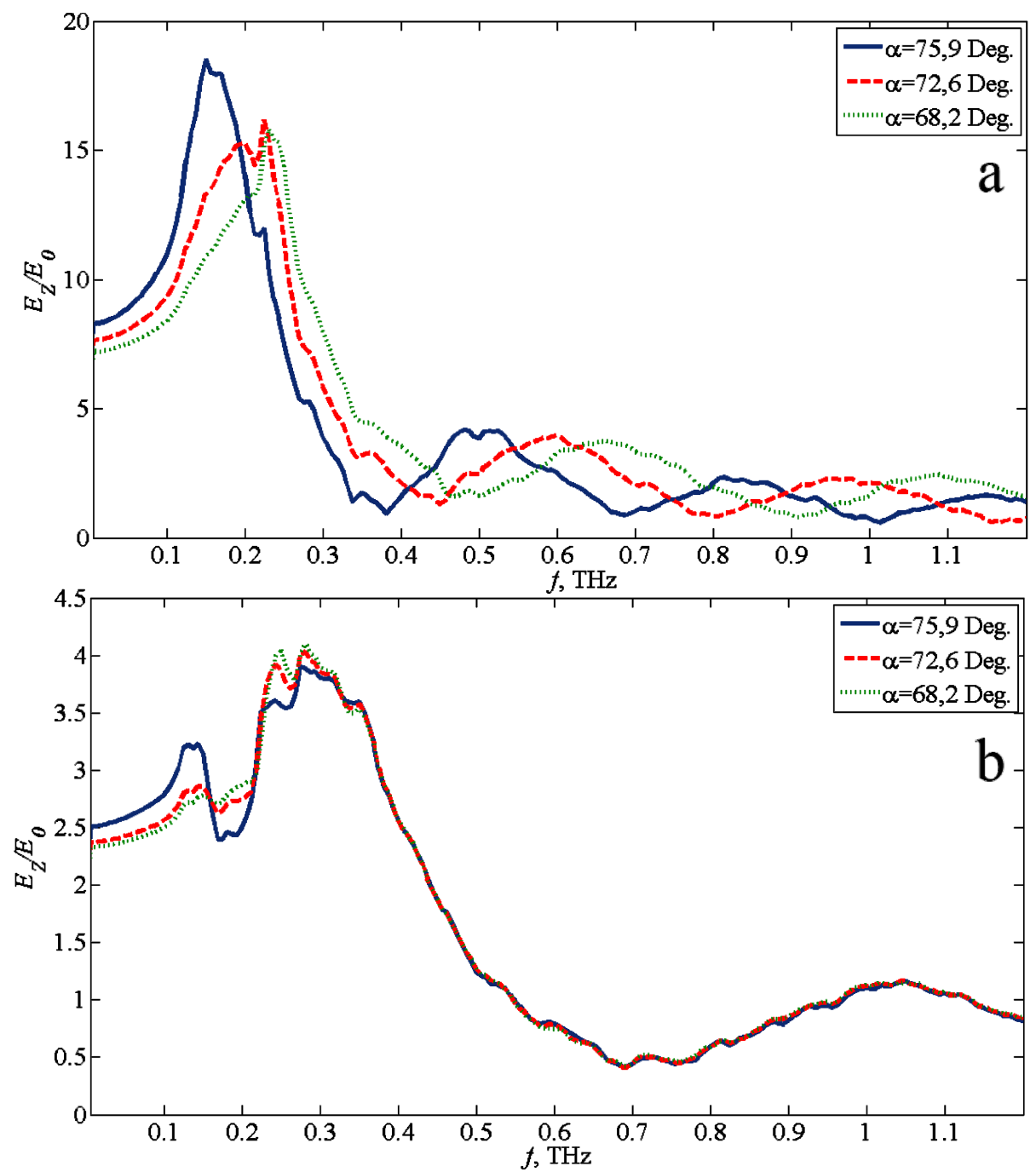

Fig. 3. Electric field amplitude $E_{z}$ and incident wave amplitude $E_{0}$ ratio dependence on frequency, under different values of angle $\alpha$. Electric field distributions were simulated at (a) zone 2 and (b) zone 1. Simulation resolution and step number were constant.

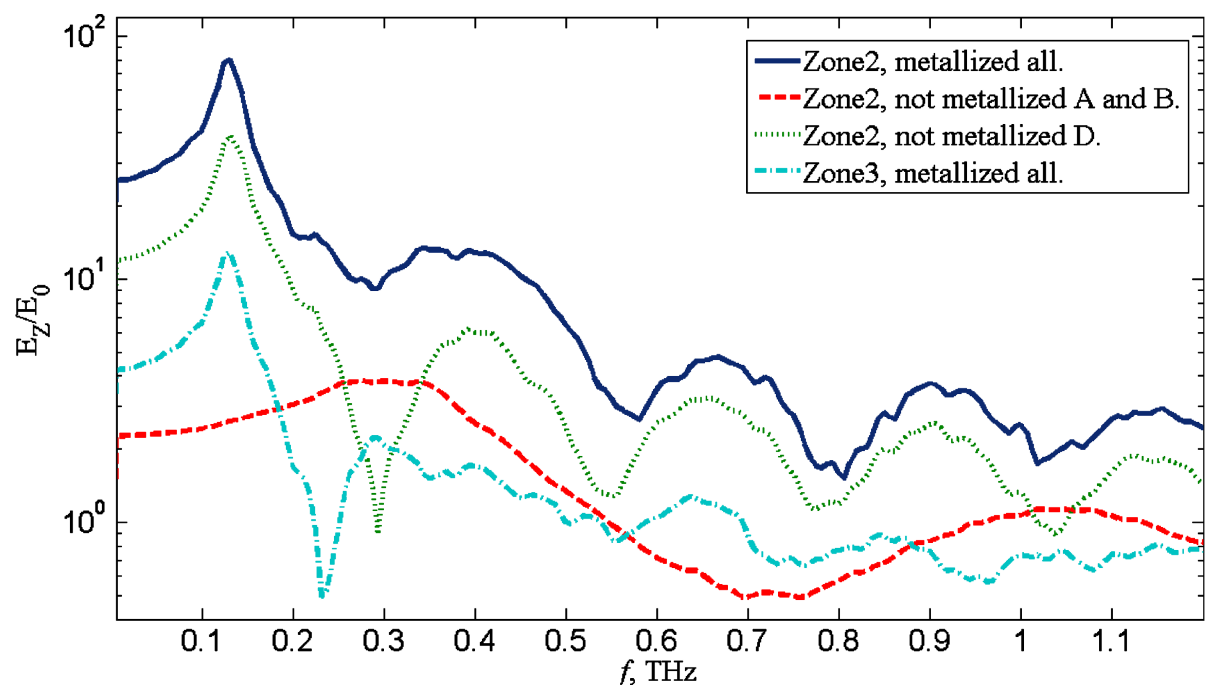

Fig. 4. Electric field amplitude $E_{z}$ and incident wave amplitude $E_{0}$ ratio dependence on frequency when the metallization parts were changed. Electric field distributions were simulated at zone 2 and zone 1 when angle $\alpha$ was $80.4^{\circ}$, resolution and step number were kept constant. 
diode metallization areas. The results are shown in Fig. 4. In this case, metal was "removed" from $A$ and $B$ parts or only from $D$ part, and electric field was registered at zone 2 (which is one cell below $D$ part) or at zone 3. For easier comparison, data from the earlier full metallization case is also presented. As one can see, all peaks from the 1st spectrum (solid line) and the 3rd spectrum (dotted line) have the same frequency, but the amplitude is smaller for the case when $D$ part is not metallized (dotted line). This effect appears because the electric field in this case is not concentrated in a small area between metallized surfaces. Electric field spectrum when just $D$ part is metallized (dotted line) explains why in the case of full metallization the electric field decrease between the first and the second peaks in the 1st spectrum is not observed (deep minimum at $0.3 \mathrm{THz}$, as it appears in the 3rd spectrum). Its first amplitude maximum at $0.25-0.3 \mathrm{THz}$ (dashed line) compensates the minimum caused by $A$ and $B$ parts, helping to maintain the electric field amplitude between the metal contacts.

\subsection{Evaluation of the effective refractive index}

As one can clearly see from results presented in Table 2 , the average effective refractive index remains in $n_{\mathrm{eff}}=1.48 \pm 0.11$ range. This value did not change when the combined length of $A+B$ parts of the detector was changed from 0.225 to $0.395 \mathrm{~mm}$ and the angle $\alpha$ from 80.4 to $68.2^{\circ}$ correspondingly. This effective refractive index value can be used to estimate the electric field amplitude maxima position in frequency scale for other lengths or angles of detector $A$ and $B$ parts. For example, if combined length of $A$ and $B$ parts in $z$ direction is extended from 0.4 to $0.5 \mathrm{~mm}$, one can estimate that the first resonance frequency ( $E$ maximum), would shift from 0.125 to $0.10 \mathrm{THz}$. Estimation of the same effective refractive index for $D$ part was not so accurate. Therefore, if dimensions of $D$ part were changed, detector properties would be evaluated only after further simulation.

\subsection{Comparison of theoretical and experimental results}

Previous experimental studies have demonstrated that the detector sensitivity decreases with frequency more rapidly than can be expected from the phenomenological model [10]. Therefore, to get a more detailed picture, the sensor sensitivity at different frequencies can be evaluated using the approach given here.
It was known from the experiment that the detector output signal is directly proportional to $\mathrm{THz}$ radiation power or to the square of the electric field amplitude [10]. This fact is used to find the detector sensitivity. Electrons are heated by the local field, which is concentrated by antennas (contact pads) in an active region. This heating should not depend on how this electric field is increased - by increasing the laser radiation power (done during the experiment), or improving the electric field concentration in the apex area by changing shapes and dimensions of the antenna parts. Therefore, phenomenological sensitivity evaluation model can be "corrected" by including the frequency dependent ratio of the electric field amplitude squared at different frequencies (Fig. 5). Dashed line in this graph corresponds to the calculated detector sensitivity if both - the antenna effects and the phenomenological model estimating carrier relaxation time - are evaluated. Dotted line shows the simulated $\left(E_{z} / E_{0}\right)^{2}$ distribution dependence on frequency. The fixed multiplier in phenomenological model is chosen so that the experimental and theoretical points match at $0.7 \mathrm{THz}$ frequency, where both experimental and theoretical data are available. As one can see, this curve better matches experimental results than in the case of "uncorrected" model. It is also important to note that when an evaluation of the data overlap is made, the full range of sensitivity between the resonance peaks and the "bottoms of holes" should be taken into account, because the attached contact wires could influence the precise positions of resonance maxima during the experiment.

Finally, it deserves noting that the antenna/coupling related effects could be responsible for the deviations from the monotonical frequency dependence of the sensitivity within 1-2 THz range also in an asymmetrically shaped planar GaAs diodes containing $n-n^{+}$junctions [12].

\section{Conclusions}

Electric field distribution dependence on detector shape was presented. By including all the observed factors, some explanations are given to the experimental data presented in [9] and [10]. The observed reduction of the sensitivity is attributed to the reduction of coupling efficiency due to the antenna properties of the detector contacts. Two different resonance frequencies of two separate parts of antenna explain the scattered experimental points. Moreover, an estimated effective average refractive index of the region around the antenna remains nearly constant, $n_{\mathrm{eff}}=1.48 \pm 0.11$, 


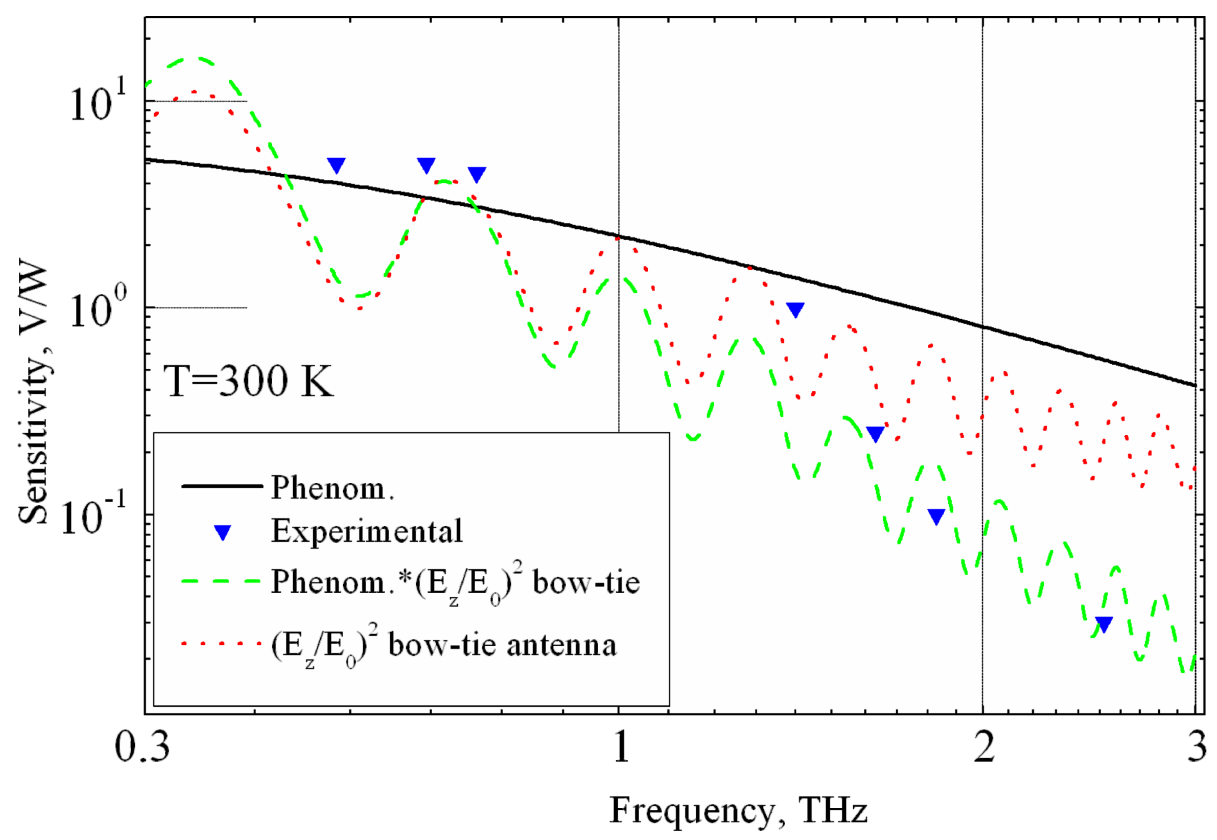

Fig. 5. Sensitivity dependence of the InGaAs bow-tie diode on frequency in THz frequency region. Phenomenological calculation marked with a black line. Experimental data [10] marked as triangle symbols. Simulated bow-tie sensitivity dependence on frequency, in which corrected phenomenological model and bow-tie detector simulation results have been evaluated, is depicted by dashed line (green online). Simulated $\left(E_{z} / E_{0}\right)^{2}$ distribution dependence on frequency is shown by a dotted line.

for all investigated angles and dimensions. This value could be used for the estimation of frequency dependent properties in the case of other bow-tie detector shapes and sizes even without further time consuming simulations. Finally, it was shown that the "corrected" phenomenological model (with antenna effects inclusion) better matches experimental results at frequencies above $1 \mathrm{THz}$.

\section{Acknowledgements}

One of the authors, Linas Minkevičius, acknowledges the Student Research Fellowship Award from the Lithuanian Science Council in 2009 and 2010. The research, in part, was supported by the Lithuania State Science and Studies Foundation (C-07004/C-17/2009).

\section{References}

[1] B.N. Behnken, G. Karunasiri, D.R. Chamberlin, P.R. Robrish, and J. Faist, Real-time imaging using a $2.8 \mathrm{THz}$ quantum cascade laser and uncooled infrared microbolometer camera, Opt. Lett. 33, 440-442 (2008).

[2] W. Knap, Y. Deng, S. Rumyantsev, J.-Q. Lü, M.S. Shur, C.A. Saylor, and L.C. Brunel, Resonant detection of subterahertz radiation by plasma waves in a submicron field-effect transistor, Appl. Phys. Lett. 80, 3433-3435 (2002).
[3] A. Lisauskas, U. Pfeiffer, E. Öjefors, P. Haring Bolìvar, D. Glaab, and H.G. Roskos, Rational design of high-responsivity detectors of terahertz radiation based on distributed self-mixing in silicon field-effect transistors, J. Appl. Phys. 105, 114511 (2009).

[4] A. Lisauskas, W. von Spiegel, S. Boubanga-Tombet, A. El Fatimy, D. Coquillat, F. Teppe, N. Dyakonova, W. Knap, and H.G. Roskos, Terahertz imaging with GaAs field-effect transistors, Electron. Lett. 44, 408409 (2008).

[5] W. Knap, M. Dyakonov, D. Coquillat, F. Teppe, N. Dyakonova, J. Łusakowski, K. Karpierz, M. Sakowicz, G. Valusis, D. Seliuta, I. Kasalynas, A. El Fatimy, Y. Meziani, and T. Otsuji, Field effect transistors for terahertz detection: Physics and first imaging applications, J. Infrared Millimet. Terahz. Waves 30, 13191338 (2009).

[6] S. Nadar, H. Videlier, D. Coquillat, F. Teppe, N. Dyakonova, W. Knap, G. Valusis, D. Seliuta, and I. Kasalynas, Terahertz imaging using a GaAs field effect transistor as plasma wave detector [submitted to J. Appl. Phys. (2010)].

[7] M Lee, M.C. Wanke, and J.L. Reno, Millimeter wave mixing using plasmon and bolometric response in a double-quantum-well field-effect transistor, Appl. Phys. Lett. 86, 033501 (2005).

[8] I. Kašalynas, D. Seliuta, R. Simniškis, V. Tamošiūnas, K. Köhler, and G. Valušis, Terahertz imaging with bow-tie InGaAs-based diode with broken symmetry, Electron. Lett. 45, 833-835 (2009). 
[9] D. Seliuta, E. Širmulis, V. Tamošiūnas, S. Balakauskas, S. Ašmontas, A. Sužiedèlis, J. Gradauskas, G. Valušis, A. Lisauskas, H.G. Roskos, and K. Köhler, Detection of terahertz/sub-terahertz radiation by asymmetrically-shaped 2DEG layers, Electron. Lett. 40, 631-632 (2004).

[10] D. Seliuta, I. Kašalynas, V. Tamošiūnas, S. Balakauskas, Z. Martūnas, S. Ašmontas, G. Valušis, A. Lisauskas, H.G. Roskos, and K. Köhler, Silicon lens-coupled bow-tie InGaAs-based broadband tera- hertz sensor operating at room temperature, Electron. Lett. 42, 825-827 (2006).

[11] A. Taflove, in: Computational Electrodynamics: The Finite-Difference Time Domain Method, 2nd ed. (Norwood: Artech House, 2000) p. 866.

[12] A. Sužiedèlis, S. Ašmontas, J. Gradauskas, G. Valušis, and H.G. Roskos, Giga- and terahertz frequency band detector based on an asymmetricallynecked $n-n^{+}$-GaAs planar structure, J. Appl. Phys. 93, 3034-3038 (2003).

\title{
PETELIŠKĖS FORMOS InGaAs DETEKTORIŲ DAŽNINĖS SAVYBĖS TERAHERCŲ SRITYJE
}

\author{
L. Minkevičius ${ }^{a, b}$, I. Kašalynas ${ }^{a}$, D. Seliuta ${ }^{a}$, V. Tamošiūnas ${ }^{\text {a,b }}$, G. Valušis a,b \\ ${ }^{a}$ Fiziniu ir technologijos mokslu centro Puslaidininkiu fizikos institutas, Vilnius, Lietuva \\ ${ }^{\mathrm{b}}$ Vilniaus universitetas, Vilnius, Lietuva
}

\section{Santrauka}

Pateikti trimačio elektromagnetinių bangų sklidimo modeliavimo baigtinių skirtumų laiko skaleje (finite difference time domain - FDTD) [11]) metodu gauti rezultatai ìvairiu matmenu peteliškiu formos detektoriams. Tyrimo metu buvo keičiami abieju metalizuotų dalių ilgiai, kampas ties apatinès dalies smaile bei nagrinejjama šiu pokyčių ittaka elektrinio lauko spektrui. Nustatyta, kad tiriamo detektoriaus veikimą nulemia elektrinio lauko pasiskirstymo nevienalytiškumas dvimačių elektronų sluoksnyje, todèl tikè- tina, kad didžiausią ịtaką dažninėms detektoriaus savybėms turès elektrinio lauko stiprio priklausomybė nuo dažnio siaurojoje dalyje ties smaile. Teorinio tyrimo metu išryškejjo keletas esminių dèsningumų. Nustatyta, kad du atskirti metalizuoti kontaktai veikia kaip dvi atskiros antenos su aiškiai išreikštomis rezonansinèmis savybèmis. Parodyta, kad didejjant dažniui lokalių maksimumų, susijusių su antenų efektais, amplitudė mažèja, ir tai leidžia paaiškinti, kodèl eksperimento metu buvo stebimas greitesnis už fenomenologinio modelio numatytaji jautrio mažejimas. 